\title{
AQUEOUS MEDIATED DIELS-ALDER REACTION: A SIMPLE ROUTE TO THE SYNTHESIS OF PIPERIZINE DERIVATIVES
}

\author{
Rasheeth Ahmed Khan ${ }^{1}$, Lakshmi Krishnamoorthy ${ }^{2}$ and Karthik S $^{2}$ \\ 1 Department of General Studies, Yanbu Industrial College, \\ Yanbu-Al Sinaiyah, Kingdom of Saudi Arabia \\ Email:drrasheeth@gmail.com \\ 2 Post Graduate \& Research Department of Chemistry, The New College (Autonomous), \\ (Affiliated to University of Madras), Chennai-6000 014, India
}

\begin{abstract}
Water is the most environmentally benign inexpensive solvent, and therefore aqueous mediated organic reactions constitute the ideal green chemistry. We herein report an environment friendly Diels - Alder reaction of biologically active dihydropyrimidine (DHPM) as dienophile with glyoxime, dimethyl glyoxime and diaminoglyoxime as diene using water as solvent. Though the reaction was slow at room temperature, rate enhancement was observed when it was carried out at the reflux temperature. Further the reaction was also found to proceed smoothly with N-phenyl maleimide as dienophile.
\end{abstract}

\section{Keywords: Green Chemistry, Diels-Alder Reaction, Biginelli Reaction, Aqueous Mediated Organic Reaction, Dihydropyrimidines.}

\section{INTRODUCTION}

Green chemistry is a convenient and rapid synthetic procedure. It is the design of chemical products and processes that reduce or eliminate the use and generation of hazardous substances. The chemistry of living organisms depends on its combination of unusual properties, and it is difficult to imagine life in the absence of the aqueous medium. However, for synthetic organic chemistry, water is traditionally not a popular choice of solvent. This is due to the fact that the most of organic molecules are nonpolar, and so hydrophobic and generally highly insoluble in water. Further functional groups in the organic molecule may themselves react with water. It is therefore assumed that a mixture of water and one or more nonpolar organic reactants will usually have low reaction rates and low yields of the desired products.

Ever since the pioneering report by Breslow [1] on Diels-Alder reaction that it can be accelerated by using water as a solvent, considerable attention has been directed toward the development of organic reactions in water [2]. Narayan et al reported a remarkable phenomenon: they found that the reaction was substantially accelerated when insoluble reactants were stirred in an aqueous suspension; this was denoted as the "on water" condition [3].

Recently many excellent reviews are reported on aqueous mediated organic reactions [4]. The discovery of biologically active molecules is essential for both the development of new therapeutics and to provide tools for the elucidation of cellular processes [5]. The method of effecting efficient chemical 
transformation coupling three or more components in a single operation by a catalytic process avoiding toxic reagents, large amount of solvents and expensive purification technique represents a fundamental target of the modern organic synthesis which can be easily achieved by multi component reactions (MCRs) [6-9]. One such MCR is the synthesis of dihydropyrimidine using Biginelli reaction [10].

Dihydropyrimidines (DHPM) found to possess remarkable pharmacological properties such as antihypertensive, anticarcinogenic, antibacterial and calcium channel blockers [11-17]. Even some of the naturally occurring marine alkaloids containing DHPM unit found to inhibit HIVgp120 [18]. Further, these DHPMs contain an activated double bond, which can be used as an effective dienophile in Diels-Alder reaction. Pratiba Sharma and co-workers have reported [19] the synthesis of pyrimido [4, 5-d] pyrimidine analogues by hetero Diels-Alder cycloaddition of 6-methyl-4-phenyl-2-thioxo-1,2,3,4tetrahydropyrimidine-5-carboxylic acid methyl ester, a Biginelli compound with $\mathrm{N}$ arylidine- $\mathrm{N}$-methylformamidines and $\mathrm{N}$ arylidine guanidine in dry toluene. This prompted us to synthesize various DHPM derivatives using Diels-Alder reaction in environmentally benign condition.

\section{RESULTS AND DISCUSSION}

\section{1. SYNTHESIS OF DIHYDROPYRIMIDINE}

A grindstone method was adopted to synthesize the dihydropyrimidine (DHPM) [20]. Thus the pyrimidine analogue, 6methyl-4-(2-chloro)phenyl-2-thioxo-1,2,3,4tetrahydropyrimidine-5-carboxylic acid ethyl ester (1) was prepared when a mixture of 2chloro benzaldehyde, ethyl acetoacetate and thiourea was ground with orthophosphoric acid when a colorless solid separated.

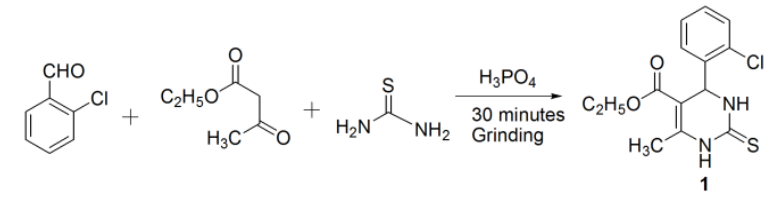

Scheme 1 Grindstone reaction in the preparation of DHPM

\section{2: DIELS-ALDER REACTION OF DHPM AS DIENOPHILE}

The various dienes used in this study are glyoxime, dimethylglyoxime and diaminoglyoxime. Among these dienes, dimethyl glyoxime was used from the commercially available source. Glyoxime and diaminoglyoxime were synthesized from glyoxal using the method reported in the literature [21-22].

The dienophile (1) was first mixed with glyoxime, dimethylglyoxime and diaminoglyoxime in a 1:1 mole ratio and ground into fine particles using mortar and pestle. This improves the surface area of reacting particles and thereby enhancing the rate of reaction. This fine particle mixture was added to a $100 \mathrm{ml}$ round bottomed flask containing $50 \mathrm{ml}$ of water and stirred at room temperature. The reaction was monitored using thin layer chromatography (TLC) which showed no new spot. Then the reaction mixture was refluxed using water bath for about 12 hrs when TLC showed a new spot. The flask was cooled and the product obtained was filtered. The pure cycloadduct 2 was isolated using a column of silica gel (1:10ethyl acetate: hexane). The results are tabulated in Table 1.

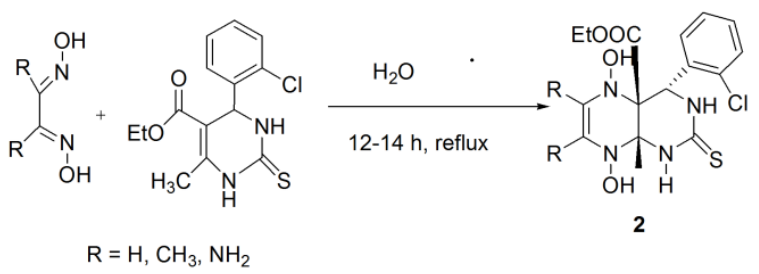

Scheme 2 Synthesis of piperizine derivatives using DHPM

The IR spectrum of the Diels- Alder cycloadduct 2 a showed the presence of $\mathrm{NH}$ absorptions at $3216 \& 3225 \mathrm{~cm}^{-1}$ and $\mathrm{OH}$ 
absorption at $3321 \mathrm{~cm}^{-1}$. The presence of $\mathrm{C}=\mathrm{O}$ and $\mathrm{C}=\mathrm{C}$ were confirmed by absorptions at $1702 \& 1420 \mathrm{~cm}^{-1}$ respectively. A substantial evidence for the formation of cycloadduct 2 can be noticed from NMR spectrum where in methyl protons of pyrimidine ring of DHPM shifted from $2.3 \delta$ to $1.6 \delta$. Moreover a doublet at $5.9 \delta$ showed the presence of alkene protons. The mass spectrum of $2 \mathrm{a}$ showed the value for $\mathrm{m} / \mathrm{z}$ at 398 . These spectral data confirmed the formation of the Diels-Alder cycloadduct 2a. Similarly the structures of the compounds $2 \mathrm{~b}$ and $2 \mathrm{c}$ were confirmed by IR, NMR \& HRMS.

TABLE 1: DIELS-ALDER REACTION OF DHPM AS DIENOPHILE

\begin{tabular}{|c|c|c|c|c|c|}
\hline S.No & $\begin{array}{c}\text { Entr } \\
\mathrm{y}\end{array}$ & Diene & $\begin{array}{c}\text { Time } \\
\text { (h) }\end{array}$ & $\begin{array}{c}\text { Yield } \\
(\%)\end{array}$ & M.P $\left({ }^{\circ} \mathrm{C}\right)$ \\
\hline 1 & $2 \mathrm{a}$ & Glyoxime & 12.0 & 62 & $195-197$ \\
\hline 2 & $2 \mathrm{~b}$ & $\begin{array}{c}\text { dimethyl } \\
\text { glyoxime }\end{array}$ & 13.0 & 56 & $157-159$ \\
\hline 3 & $2 \mathrm{c}$ & $\begin{array}{c}\text { Diaminoglyoxi } \\
\text { me }\end{array}$ & 13.5 & 64 & $150-152$ \\
\hline
\end{tabular}

2. 3. DIELS-ALDER REACTION OF N-PHENYL MALEIMIDE AS DIENOPHILE

Exploiting the versatility of the above DielsAlder reaction, different heterocyclic compounds were prepared by changing the dienophile from DHPM to N-phenyl maleimide while keeping the same dienes viz., glyoxime, dimethylglyoxime and diaminoglyoxime by employing the above procedure. The $[4+2]$ cycloaddition reaction proceeded slightly faster with $\mathrm{N}$-phenyl maleimide as a dienophile than DHPM. This may be due to the steric factor that operates in DHPM. The results are tabulated in Table 2.

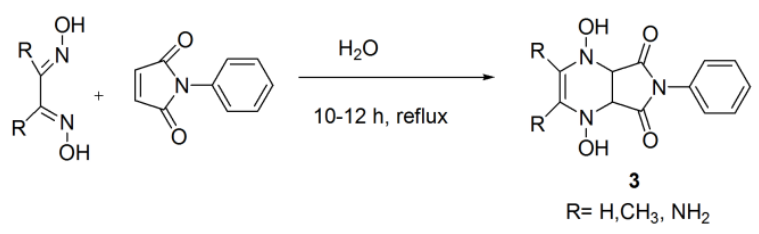

Scheme 3. Synthesis of piperizine derivatives using N-phenyl maleimide
TABLE 2: DIELS-ALDER REACTION OF N-PHENYL MALEIMIDE AS DIENOPHILE

\begin{tabular}{|c|c|l|c|c|c|}
\hline S.No & Entry & \multicolumn{1}{|c|}{ Diene } & Time (h) & $\begin{array}{c}\text { Yield } \\
(\%)\end{array}$ & $\begin{array}{c}\text { M.P } \\
\left({ }^{\circ} \mathrm{C}\right)\end{array}$ \\
\hline 1 & $3 \mathrm{a}$ & Glyoxime & 10.0 & 64 & $130-132$ \\
\hline 2 & $3 \mathrm{~b}$ & dimethyl glyoxime & 11.0 & 58 & $210-211$ \\
\hline 3 & $3 \mathrm{c}$ & diaminoglyoxime & 11.5 & 69 & $123-124$ \\
\hline
\end{tabular}

The cycloadduct $3 \mathrm{a}$ showed the IR absorptions at $3256 \mathrm{~cm}^{-1}$ for $-\mathrm{OH}$ stretching frequency. A strong and sharp absorption at $1708 \mathrm{~cm}^{-1}$ showed the presence of $\mathrm{C}=\mathrm{O}$ stretching frequency. The PMR of 3 a showed a doublet at $2.1 \delta$ confirmed the presence of two methine protons. A doublet at $5.4 \delta$ showed the presence of alkene protons in piperizine ring. A multiplet at $7.3 \delta$ shows the presence of five protons of aromatic ring. A singlet at $7.5 \delta$ confirmed the presence of $-\mathrm{OH}$ proton. Further HRMS of compound 3a showed the molecular ion peak at $\mathrm{m} / \mathrm{z}=$ 261. From the above spectral data it can be rationalized that the structure of $3 \mathrm{a}$ is due to the formation of $[4+2]$ cycloadduct from Diels-Alder reaction of $\mathrm{N}$-phenyl maleimide with glyoxime. Similarly the formation of compounds $3 b$ and $3 c$ were confirmed by their respective spectral data.

\section{EXPERIMENTAL}

\subsection{GENERAL CONSIDERATIONS}

All melting and boiling points are uncorrected. IR spectra were recorded using Perkin- Elmer 598 FT-IR spectrophotometer. ${ }^{1} \mathrm{H}$ NMR spectra were taken using JEOL GSX (500 $\mathrm{MHz}$ ) instrument with $\mathrm{CDCl}_{3}$ as solvent and TMS as the internal standard. The chemical shifts are reported in $\delta$-scale. Mass spectra were recorded using Varian $\mathrm{MatCH}-7$ and JEOL DX-303 spectrometer. TLC was run over glass plates coated with silica gel-G (ACME) sample of $0.25 \mathrm{~mm}$ thickness and visualized using iodine. Anhydrous $\mathrm{Na}_{2} \mathrm{SO}_{4}$ was used as drying agent. Purification of compounds was done using column 
chromatography over silica gel of 60-120 mesh. Petroleum ether refers to the fraction boiling in the range $60-80^{\circ} \mathrm{C}$. All other chemicals used were of A. R. grade and were used without further purification.

\section{2. SYNTHESIS OF DHPM [20] (1)}

A mixture of o-chlorobenzaldehyde (1 mmol) ethyl acetoacetate $(1 \mathrm{mmol})$ and thiourea $(1.17 \mathrm{mmol})$ was ground with orthophosphoric acid $(0.5 \mathrm{ml})$ for about 30 minutes. After completion of the reaction (monitored by TLC) the reaction mixture was cooled to room temperature and poured into ice cold water $(100 \mathrm{ml})$ and allowed to stand for 30 minutes when solid separated. The resulting solid was filtered off, dried and then recrystallised from ethanol to give the product 1. Melting point of the solid was found to be $215-216^{\circ} \mathrm{C}$ (Lit. $212-214^{\circ} \mathrm{C}$ [23]

\subsection{SYNTHESIS OF CYCLOADDUCT (2)}

A mixture of DHPM $(0.58 \mathrm{~g}, 2 \mathrm{mmol})$ and diene (glyoxime or dimethyl glyoxime or diaminoglyoxime) (2 $\mathrm{mmol})$ was added to 50 $\mathrm{ml}$ of water taken in a $100 \mathrm{ml}$ round bottom flask. The reaction mixture was refluxed for about $12-13 \mathrm{~h}$ and the reaction was monitored using TLC which showed a new spot. The residue obtained was filtered and purified by silica gel column chromatography eluting with ethyl acetate: hexane $(10 \%)$ to give the desired solid products $2 \mathrm{a}-\mathrm{c}$.

\subsection{SYNTHESIS OF CYCLOADDUCT (3).}

A mixture of $\mathrm{N}$-phenylmalimide $(0.346 \mathrm{~g}, 2$ $\mathrm{mmol}$ ) and diene (glyoxime or dimethyl glyoxime or diaminoglyoxime) ( $2 \mathrm{mmol}$ ) was added to $50 \mathrm{ml}$ of water taken in a $100 \mathrm{ml}$ round bottom flask. The reaction mixture was refluxed for about $10-12 \mathrm{~h}$ the reaction was monitored using TLC which showed a new spot. The residue obtained was filtered and purified by silica gel column chromatography eluting with ethyl acetate: hexane (10\%) to give the desired solid products $3 \mathrm{a}-\mathrm{c}$.

\section{SPECTRAL DATA}

4.1. SPECTRAL DATA FOR 4-(2-CHOROPHENYL)-5,8-DIHYDROXY-8A-METHYL-2-THIOXO1,3,4,5,8,8A-HEXAHYDRO-2H-PTERIDINE-4ACARBOXYLIC ACID ETHYL ESTER (2A)

IR(KBr) $v_{\max }: 1420 \mathrm{~cm}^{-1}, 1702 \mathrm{~cm}^{-1}, 3216 \mathrm{~cm}^{-1}$, $3225 \mathrm{~cm}^{-1}, 3321 \mathrm{~cm}^{-1} .{ }^{1} \mathrm{H}$ NMR $\left(\mathrm{CDCl}_{3}\right): \delta$ $1.2(\mathrm{t}, 3 \mathrm{H}$, methyl protons of ester), $1.6(\mathrm{~s}, 3 \mathrm{H}$, methyl protons of pyrimidine ring), $2.2(\mathrm{~s}, 1 \mathrm{H}$, methine proton), 4.0 (q, 2H, methylene protons of ester), $5.9(\mathrm{~d}, 2 \mathrm{H}$, alkene protons of piperizine ring), $7.3-7.4(\mathrm{~m}, 4 \mathrm{H}$, aromatic protons),7.9 (s, $\mathrm{NH}$ protons, $\mathrm{D}_{2} \mathrm{O}$ exchangeable), 8.6 (s, OH protons, $\mathrm{D}_{2} \mathrm{O}$ exchangeable). EI mass spectrum: $\mathrm{m} / \mathrm{z}=416$ $\left(\mathrm{M}^{+}\right)$.

4.2. SPECTRAL DATA FOR 4-(2-CHOROPHENYL)-5,8-DIHYDROXY-6,7,8A-TRIMETHYL-2THIOXO-1,3,4,5,8,8A-HEXAHYDRO-2H-PTERIDINE4A-CARBOXYLIC ACID ETHYL ESTER (2B)

IR(KBr) $v_{\max }: 1439 \mathrm{~cm}^{-1}, 1688 \mathrm{~cm}^{-1}, 3245 \mathrm{~cm}^{-}$ ${ }^{1}, 3260 \mathrm{~cm}^{-1}, 3392 \mathrm{~cm}^{-1} .{ }^{1} \mathrm{H} \mathrm{NMR}\left(\mathrm{CDCl}_{3}\right): \delta$ $1.3(\mathrm{t}, 3 \mathrm{H}$, methyl protons of ester), $1.5(\mathrm{~s}, 3 \mathrm{H}$, methyl protons of pyrimidine ring), $2.3(\mathrm{~s}, 1 \mathrm{H}$, methine proton), $3.2(\mathrm{~s}, 6 \mathrm{H}$, methyl protons of piperizine ring), $3.8(\mathrm{q}, 2 \mathrm{H}$, methylene protons of ester), $7.0-7.5(\mathrm{~m}, 4 \mathrm{H}$, aromatic protons), $8.1\left(\mathrm{~s}, \quad \mathrm{NH}\right.$ protons, $\mathrm{D}_{2} \mathrm{O}$ exchangeable), $8.4\left(\mathrm{~s}, \mathrm{OH}\right.$ protons, $\mathrm{D}_{2} \mathrm{O}$ exchangeable). EI mass spectrum: $\mathrm{m} / \mathrm{z}=426$ $\left(\mathrm{M}^{+}\right)$.

4.3. SPECTRAL DATA FOR 6,7-DIAMINO-4-(2CHORO-PHENYL)-5,8-DIHYDROXY-8A-METHYL-2THIOXO-1,3,4,5,8,8A-HEXAHYDRO-2H-PTERIDINE4A-CARBOXYLIC ACID ETHYL ESTER (2C)

IR(KBr) $v_{\text {max }}: 1415 \mathrm{~cm}^{-1}, 1691 \mathrm{~cm}^{-1}, 3180 \mathrm{~cm}^{-1}$, $3202 \mathrm{~cm}^{-1}, 3374 \mathrm{~cm}^{-1}$. ${ }^{1} \mathrm{H}$ NMR $\left(\mathrm{CDCl}_{3}\right): \delta$ $1.1(\mathrm{t}, 3 \mathrm{H}$, methyl protons of ester), $1.4(\mathrm{~s}$, $3 \mathrm{H}$, methyl protons of pyrimidine ring), 2.4 (s, $1 \mathrm{H}$, methine proton), $3.9(\mathrm{q}, 2 \mathrm{H}$, methylene protons of ester), $6.4(\mathrm{~s}, 4 \mathrm{H}, \mathrm{NH}$ 
protons, $\mathrm{D}_{2} \mathrm{O}$ exchangeable), 7.2-7.6 $(\mathrm{m}, 4 \mathrm{H}$, aromatic protons), $7.8 \delta\left(\mathrm{s}, \mathrm{NH}\right.$ protons, $\mathrm{D}_{2} \mathrm{O}$ exchangeable), 4.9 (s, OH protons, $\mathrm{D}_{2} \mathrm{O}$ exchangeable). EI mass spectrum: $\mathrm{m} / \mathrm{z}=428$ $\left(\mathrm{M}^{+}\right)$.

\subsection{SPECTRAL DATa For 1,4-DihydROXY-6- PHENYL-1,4,4A,7A-TETRAHYDRO-PYRROLO[3,4- B]PYRAZINE-5,7-DIONE (3A)}

IR(KBr) $v_{\max }: 1708 \mathrm{~cm}^{-1}, \quad 3256 \mathrm{~cm}^{-1} .{ }^{1} \mathrm{H}$ NMR $\left(\mathrm{CDCl}_{3}\right): \delta 2.1(\mathrm{~d}, 2 \mathrm{H}$, methine protons), $5.4(\mathrm{~d}, 2 \mathrm{H}$, alkene protons of piperizine ring, $7.3(\mathrm{~m}, 5 \mathrm{H}$, aromatic protons), 7.5(s, OH protons, $\mathrm{D}_{2} \mathrm{O}$ exchangeable). $\mathrm{EI}$ mass spectrum: $\mathrm{m} / \mathrm{z}=261\left(\mathrm{M}^{+}\right)$.

4.5. SPECTRAL DATA FOR 1,4-Dihydroxy-2,3DIMETHYL-6-PHENYL-1,4,4A,7A-TETRAHYDROPYRROLO[3,4-B]PYRAZINE-5,7-DIONE (3B)

IR(KBr) $v_{\text {max }}: 1713 \mathrm{~cm}^{-1}, \quad 3280 \mathrm{~cm}^{-1} .{ }^{1} \mathrm{H} \quad \mathrm{NMR}$ $\left(\mathrm{CDCl}_{3}\right): 2.2 \delta(\mathrm{d}, 2 \mathrm{H}$, methine protons), $2.4(\mathrm{~s}, 6 \mathrm{H}$, methyl protons of piperizine ring , 4.8(s, $\mathrm{OH}$ protons, $\mathrm{D}_{2} \mathrm{O}$ exchangeable), 7.1$7.4(\mathrm{~m}, 5 \mathrm{H}$, aromatic protons $)$. EI mass spectrum: $\mathrm{m} / \mathrm{z}=289\left(\mathrm{M}^{+}\right)$.

4.6. SPECTRAL DATA FOR 2,3-Diamino-1,4DIHYDROXY-6-PHENYL-1,4,4A,7A-TETRAHYDROPYRROLO[3,4-B]PYRAZINE-5,7-DIONE 3C:

IR(KBr) v $v_{\text {max }}: 1698 \mathrm{~cm}^{-1}, \quad 3250 \mathrm{~cm}^{-1} .{ }^{1} \mathrm{H}$ NMR $\left(\mathrm{CDCl}_{3}\right): 2.1 \delta(\mathrm{d}, 2 \mathrm{H}$, methine protons), $6.2(\mathrm{~s}, 4 \mathrm{H}, \mathrm{NH}$ protons of piperizine ring , $7.3(\mathrm{~m}, 5 \mathrm{H}$, aromatic protons), $7.5(\mathrm{~s}, \mathrm{OH}$ protons, $\mathrm{D}_{2} \mathrm{O}$ exchangeable). $\mathrm{EI}$ mass spectrum: $\mathrm{m} / \mathrm{z}=291\left(\mathrm{M}^{+}\right)$.

\section{CONCLUSION}

This study shows that the heterocyclic compounds containing piperizine nucleus can be easily synthesized using aqueous mediated Diels-Alder reaction of DHPMs and Nphenylmaleimide with glyoxime, dimethylglyoxime and diaminoglyoxime. It is an environmentally benign and economically viable method as it involves water as the solvent instead of traditional toxic organic solvents.

\section{ACKNOWLEDGEMENT}

Authors thank the management of The New College, Chennai for providing the necessary facilities. Authors also acknowledge the help rendered by SAIF, IIT-Chennai for recording the IR, NMR and Mass spectra.

\section{REFERENCES}

[1] a) Breslow, R. Hydrophobic Effects on Simple Organic Reactions in Water Acc. Chem. Res. Vol. 24, pp. 159-164, 1991.

b) Breslow, R. Determining the Geometries of Transition States by Use of Antihydrophobic Additives in Water Acc. Chem. Res. Vol. 37, pp.471-478, 2004.

[2] For monographs, see: (a) Li, C. J., Chan, T. H. Organic Reactions in Aqueous Media; Wiley: New York, 1997. (b) P. A. Grieco, Organic Synthesis in Water; Thomson Science: Glasgow, Scotland, 1998.

[3] a) Narayan S., Muldoon, J., Finn M., Fokin G. V. V., Kolb H. C., Sharpless K. B. "On Water": Unique Reactivity of Organic Compounds in Aqueous Suspension Angew. Chem. Int. Edn Vol. 44, 2005, pp. 3275-3279. b) Narayan S., Muldoon J., Finn M., Fokin G.V. V., Kolb H. C., Sharpless K. B. On Water": Unique Reactivity of Organic Compounds in Aqueous Suspension Angew. Chem. Int. Edn Vol. 117, pp. 3339-3343, 2005.

[4] Chanda A., Fokin V. V. Organic Synthesis "on Water”, Chem. Rev. Vol. 109, pp. 725-748, 2009.

[5] Schreiber S. L. The small-molecule approach to biology, Chem. Eng. News. Vol. 81, pp. 51-61, 2003.

[6] Ugi I., Domling A., Horl W. Multicomponent Reactions in Organic Chemistry Endeavour. Vol. 18, pp. 115-122, 1994.

[7] Armstrong R. W., Combs A. P., Tempest P. A., Brown S. D., Keating T. A. Acc. Chem. Res. Vol. 29, pp. 123-131, 1996.

[8] Dax S. L., McNally J. J., Youngman M. A. Multi-component methodologies in solid-phase 
organic synthesis Curr. Med. Chem. Vol. 6, pp. 255-270, 1999.

[9] Mizuno N., Misono M. Heterogeneous catalysis. Chem. Rev. Vol. 98, pp.199-218, 1998.

[10] Biginelli, P. Gazz. Chem. Ital. Vol.23, pp. 360416, 1893.

[11] Grover G. J., Dzwonezyk S., McMullen D. M., Normadinam C. S., Sleph P. G., Moreland S. J. Pharmacologic profile of the dihydropyrimidine calcium channel blockers SQ 32,547 and SQ 32,926 J. Cardiovasc. Pharmacol. Vol. 26, pp. 289-294, 1995.

[12] Atwal K. S., Swanson B. N., Unger S. E., Floyd D. M., Moreland S., Reilly B. C. Dihydropyrimidine calcium channel blockers.3.3.-Carbamoyl-4-aryl-1, 2, 3, 4tetrahydro-6-methylpyrimidine carboxylic acid esters as orally effective hypertensive agents J. Med. Chem., Vol. 34, pp. 806-811, 1991.

[13] Sadanandam Y. S., Shetty M.M., Diwan P. V. Synthesis and Biological Evaluation of New3,4Dihydro-6-methyl-5-N-methylcarbamoyl-4(substituted phenyl2 $(1 \mathrm{H})$ pyrimidinones and Pyrimidinethiones Eur . J. Med. Chem. Vol. 27, pp. 87-92, 1992.

[14] Overman L. E., Robinowitz M. H., Renhowe P. A. J. Am. Chem. Soc. Vol. 122, pp. 4893- 4903, 2000.

[15] Ohtani I., Kusumi T., Kakisawa H. Tetrahedron Lett. Vol. 33, pp. 2525- 2528, 1992.

[16] Jares-Erijman E. A., Sakai R., Rinehart K. L. J. Org. Chem. Vol. 56, pp. 5712-5715, 1991.

[17] Patil A. D., Freyer A. J., Taylor B., Carte B., Zuber G., Johnson R. K., Faulkner D. J. J. Org. Chem. Vol. 62, pp. $1814-1819,1997$.

[18] Patil A. D., Kumar N. V., Kokke W. C., Bean M. F., Potts B. C. M. J. Org. Chem. Vol. 60, pp. 1182-1188, 1995.

[19] Kumar A., Rane N., Gurram V., Sharma P. Tetrahedron Lett. Vol. 61, pp. 4237- 4248, 2005.

[20] Rasheeth A., Yogeshwari G., Huq C. A. M. A. J. Indian. Chem. Soc Vol. 86, pp. 950- 953, 2009.

[21] Michelman J. S., Olofson R. A., J.Org. Chem. Vol. 30 (6), pp. 1854-1857, 1965.

[22] Trudell M., Zelenin A., J. Hetr. Chem. Vol. 34, pp. 1057-1060, 1997.

[23] Susanta K., Nayak K. N., Venugopala., Deepak Chopra., Vasu and Guru Row T.
N. CrystEngComm, Vol 1216, 2010.
12, pp. 1205- 
تفاعلات ديلز ـ ألدر فى محلول مائى كوسيط : طريقة مبسطه لأصطناع مشتقات البيبرازين

$$
\begin{aligned}
& \text { رشيد احمد خان , لاكثمى كريشنامورز2 , كارسيك س2 } \\
& \text { قسم الدراسات العامة, كلية ينبع الصناعية ـ المملكة العربية السعودية }
\end{aligned}
$$

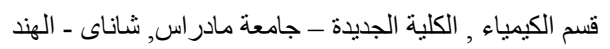

\begin{abstract}
الملخص:
الماء هو من أهم و أكثر المذيبات الاقتصادية والصديقة للبيئة ولذلك فان التفاعلات العضوية التى ببتخدم الماء فيها كمذيب يمكن اعتبارها نموذج مثالى للكيمياء الخضراء. وفى هذا البحث نم دراسة تفاعلات ديلز ألدر للمركب دايهيدرو بريميدين DHMP النشط بيولوجيا كمحب للايين مع الجليواوكزيم و الجليو اوكزيم ثنائي ميثيل و الداى امينو جليواوكزيم كديين باستخدام الماء كمذيب. على الرغم من أن رد الفعل كان بطيئا في درجة حرارة الغرفة الا انه لوحظ زيادة معدل التفاعل بالتسخين لدرجة الغليان. وعلاوة على ذلك فانه باستخدام نفينيل ماليميد كمحب للاديين تم التفاعل بسلاسه وسهولة.
\end{abstract}

